\author{
LVOV MATHEMATICAL SCHOOL \\ IN THE PERIOD 1915-45 AS SEEN TODAY \\ BANACH CENTER PUBLICATIONS, VOLUME 87 \\ INSTITUTE OF MATHEMATICS \\ POLISH ACADEMY OF SCIENCES \\ WARSZAWA 2009
}

\title{
ABOUT PROFESSOR ZDZISŁAW KRYGOWSKI ON THE 50TH ANNIVERSARY OF HIS DEATH
}

\author{
MAGDALENA JAROSZEWSKA and JULIAN MUSIELAK \\ Department of Real Functions Theory, Adam Mickiewicz University \\ Umultowska 87, PL-61-614 Poznań, Poland \\ E-mail:magjar@amu.edu.pl
}

Professor Zdzisław Krygowski was born on 22 December 1872 in Lvov. He was the son of Antoni and Henryka (maiden name: Maciulska). In 1882-1887, he attended a gymnasium in Wadowice (grades 1-5), where his father was a headmaster. He attended Gymnasium No. 3 in Cracow (grades 6-8) in 1897-1890. Having passed his secondary school exam with honours in 1890, he started studying mathematics, physics and astronomy at the Faculty of Philosophy of the Jagiellonian University. His studies lasted 9 semesters in the years 1890-1895. He attended lectures of Baraniecki, Birkenmajer, Karliński, W. Natanson, K. Olszewski, A. Witkowski and many others. In 1895, he received an excellent grade in the exam for gymnasium or real school teachers of mathematics and physics. In November of the same year, he received a Ph.D. degree at the Faculty of Philosophy of the Jagiellonian University for the work entitled On the theory of general Green functions. During his studies, he also worked in Cracow as a

2000 Mathematics Subject Classification: Primary 01A70; Secondary 40-03.

The results of the mathematical research of Zdzisław Krygowski, the list of his course handbooks and other papers (List of papers: items 1-40) will be presented elsewhere.

The authors would like to thank many people for their kind assistance in collecting and accessing the works and documents related to Zdzisław Krygowski, including: Marta Kroemeke, Witold Kroemeke and Maria Krygowska-Doniec - Z. Krygowski's family members, Professor Lech Maligranda, Professor Zbigniew Semadeni, employees of the Archives of Adam Mickiewicz University; Teresa Nowak and Halina Wydra (current and former Heads) and other employees of the Library of the Faculty of Mathematics and Computer Science at AMU, Dorota CzarnockaHead of the Library of the Institute of Mathematics of the Polish Academy of Science in Warsaw, employees of the Research Information Department at the Adam Mickiewicz University Library, employees of the Library of the Poznań Society of Friends of Arts and Sciences. Technical assistance of Waldemar Jankowski and Tomasz Piłka is also deeply appreciated.

The paper is in final form and no version of it will be published elsewhere. 


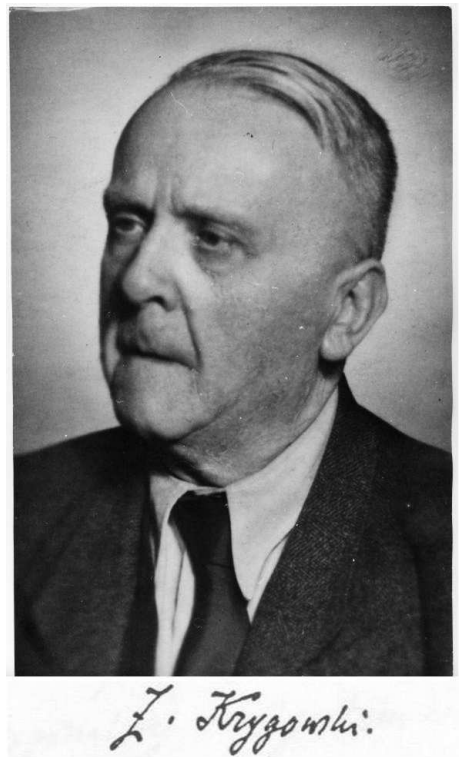

1. Professor Zdzisław Krygowski

grant holder in the astronomical laboratory in 1890/91-1892/93 and in the physical laboratory (as an assistant to Professor Witkowski) in 1892/93-1893/94. In December 1895, the Academic Senate of the Jagiellonian University awarded a three-year scholarship to Zdzisław Krygowski for further studies abroad. As a matriculated student, he studied at the University in Berlin for one semester of the academic year 1895/96, where he worked under the supervision of such well-known mathematicians as L. T. Fuchs and H. A. Schwarz. He spent the following four semesters (1896-1898) studying at Faculté des Sciences in Paris, where he attended lectures of P. Appel, E. Borel, G. Darboux, Ch. Hermite, C. Jordan, E. Picard and H. Poincaré. Picard was his scientific collaborator and a long-term friend. The contacts with these excellent mathematicians of that time determined Krygowski's research interests: analytic functions, including elliptic and hyperelliptic functions in particular. Having returned from abroad in 1898, he worked as a teacher in the Higher Real School in Cracow, in a Gymnasium in Przemyśl and in the Higher Real School in Lvov. In 1901 he started giving lectures on mathematics as an associate professor at the Faculty of Chemistry and Architecture of Lvov Polytechnic. He also gave lectures on mathematics and physics in the Higher Real School in Lvov. He had these two jobs until 1908, with a break in 1906/07 when he worked on his habilitation thesis in Paris. He received his habilitation degree in Lvov in 1908 for the thesis entitled: Sur le développement des fonctions hyperelliptiques en séries trigonométriques (see: List of works, item 8). In 1908 he took over, as Extraordinary Professor, the position at Lvov Polytechnic of the Head of the 2nd Chair of Mathematics at the Faculty of Machine Construction after Professor Kȩpiński. Later, from 1919 on, he worked as Ordinary Professor. He was the Dean of the Faculty of Water Engineering in 1913-1915 and the Rector of Lvov Polytechnic in the academic year 1917/18. 
When the University of Poznań was established in 1919, Professor Zdzisław Krygowski moved to Poznań to head, as Ordinary Professor, one of newly created Chairs of Mathematics at the Faculty of Philosophy (known as the Faculty of Mathematics and Natural Sciences after 1925). At that time, all mathematicians employed at the University of Poznań had come from other cities. The other Chair was headed by the Professor's deputy, Franciszek Włodarski who had studied in Freiburg and Göttingen, received his Ph.D. degree in 1911 and, before moving to Poznań, was the Professor of Wolna Wszechnica (Free University) in Warsaw. Kazimierz Abramowicz, the Professor's deputy joined the team in 1921. After the death of Franciszek Włodarski, the team accepted another member in 1929. It was Professor Mieczysław Biernacki who received his Ph.D. degree at the University of Paris and later worked at Stefan Batory University in Vilnius for one year.

Professor Zdzisław Krygowski determined the development of mathematics at the University of Poznań from 1919 to 1938. He was also appointed to important posts: he was elected Deputy Rector of the University of Poznań in 1919/20 and 1934-1936, and Dean of the Faculty of Philosophy in 1921/22. In the interwar period, Professor Zdzisław Krygowski was a well-known Polish mathematician, he headed the Polish Mathematical Society in 1926, he was also the Head of the Lvov Branch and the long-term Head of the Poznań Branch of this Society. In 1919, he was appointed Vice-Chairman of the first National Examination Committee for Candidates to Secondary School Teachers in Poznań. He acted as the Vice-Chairman of this Committee for many years.

His research dealt with the theory of analytic functions, differential geometry and algebra, including mainly the theory of symmetric functions with focus on the Galois theory. He published approx. 30 articles in Polish and French journals. He also authored three higher mathematics course books (see: List of works, items 21-23).

For 19 years Professor Krygowski organised scientific seminars for graduate students attended, depending on the year, by 30 up to 120 students. The participants of the seminars were interested in the theory of elliptic functions. They also worked on the following areas: the theory of analytic functions, the theory of differential equations, the theory of invariants and the theory of elliptic functions.

Krygowski's research focused not only on pure mathematics, but also on the applications of mathematics in chemistry, medicine and other fields. He cooperated with Stefan Dạbrowski, a well-known biochemist and physiologist from Poznań, thus contributing to the research on diffusion in the convection current, the dynamic theory of mineral springs and the introduction of the diffusion equation [18].

He possessed great mathematical knowledge and had wide interests. He used to write reviews of the latest books (see: List of works, items 24-30) by E. Borel, J. Hadamard and others, published both in Poland and abroad. He also wrote articles on more general topics and translated general works (see: List of works, items 31-33). He held numerous lectures at meetings of the Polish Mathematical Society and the Poznań Society of Friends of Arts and Sciences.

Professor Krygowski's work at the University of Poznań was pioneering as regards the organisation of the mathematical community in Poznań, especially in the first decade of 
the previous century. In 1929 Krygowski was awarded the Medal of the 10th Anniversary of Independence from the Rector of the University of Poznan in recognition of his work and activities.

One of the challenges faced by Professor Krygowski was the development of scientific staff and education of students. It is worth mentioning first Ph.D. degrees in mathematics obtained at the University of Poznań by Kazimierz Cwojdziński and Lidia Seipelt under the supervision of Professor Zdzisław Krygowski. Kazimierz Cwojdziński became famous in Poznań as an excellent gymnasium teacher of mathematics and Director of the Berger Gymnasium and Secondary School specialising in mathematics and physics. Lidia Seipelt was junior assistant at the Chair of Mathematics of the University of Poznań.

One of the most fundamental tasks was the organisation of a mathematical library, which is what Professor Krygowski regarded as a priority. As a result the library holdings included versatile books, such as a few volumes of Opera omnia by Leonard Euler, the latest monographs, manuals and journals. The book collection survived the Second World War and developed into a large library with tens of thousands of volumes. The authors of this article could assess the appropriateness of the choice of books and journals made by Zdzisław Krygowski when working as librarians at the beginning of their academic careers. The library is a valuable source of information necessary for scientific research and stimulates various creative initiatives.

The pioneering work (pertaining both to teaching and other areas) of the first decade of the 20th century began to bear fruit in the second decade (including academic years from 1929/30 up to 1938/39). It is evidenced by the number of graduates with the Master's degree in mathematics. The figures for the academic years from 1930/31 to 1936/37 are as follows: $3,9,30,14,26,17$ and 24 , respectively. Thus, the annual number of graduates with Master's degrees averaged at 20. As regards the number of students of mathematics in a particular year, the academic year 1936/37 is a characteristic example: year $1-33$, year $2-17$, year $3-18$, the remaining years in total - 91, graduates with the Master's degree - 24. The number of 159 students included 77 women and 82 men. Both the quantity and the quality of students were important.

Marian Rejewski, Jerzy Różycki and Henryk Zygalski provide evidence for the high quality education received in that period by the graduates of the University of Poznan with degrees in mathematics. Thanks to Professor Zdzisław Krygowski's involvement, a cryptology course for mathematics students of the University of Poznań with a good command of German was organised in Poznań in 1928/29.

Professor Krygowski supervised the course for three years. Specialist classes and lectures were held by Krygowski himself and by military and civilian employees of the General Staff in Warsaw, including Major Franciszek Pokorny, Captain Maksymilian Ciężki and engineer Antoni Palluth. The cryptology course was held as extra-curricular evening classes twice a week. The classes took place in the two-storey building of the City Headquarters at Święty Marcin Street (currently Collegium Historicum), near the former Emperor's Castle with its ground floor and basements used by the University. After the end of the course, a local branch of the Encryption Office of the General Staff of the Polish Army was temporarily established in Poznań for a few participants of the course. 
On 1 September 1932, the three above mentioned graduates of mathematics were selected from among other course participants and employed in the Encryption Office of the General Staff in Warsaw. It was them who broke the code of Enigma, the German encryption machine as early as in December. They managed to overcome the difficulties that Germans considered insurmountable. They conducted their research for many years and provided their results to France and England before the outbreak of the Second World War. That was a significant Polish contribution to the victory of the allied forces in the war. When the archives were opened in the West, one could find out how the decryption of German secret messages influenced many wartime events and battles, such as the Battle of Britain, the Battle of the Atlantic, the Invasion of Normandy, and many more. Even before the Second World War, in 1936, Professor Krygowski and the three cryptologists received the Polonia Restituta Commander's Cross and the Legion of Honour, the highest military decoration in France, and Palmes Académiques (the title of Officier d'Académie). In 1979, Marian Rejewski became the Honorary Member of the Polish Mathematical Society. In 2000, the three Polish mathematicians M. Rejewski, J. Różycki and H. Zygalski, whose achievements had not been appreciated for so long, were posthumously decorated by Prime Minister Jerzy Buzek. The mathematicians' families received the Grand Crosses of the Order of the Rebirth of Poland.

Good education of the Poznan mathematics graduates undoubtedly influenced the breaking of the Enigma code. This education was closely related to Professor Krygowski's interest in the theory of permutations. Combinatorial and probabilistic methods, and, first of all, the theory of permutations were applied to break the Enigma code. Thus, theoretical research in mathematics was applied to solving problems of great practical importance.

Extraordinary Professor Kazimierz Abramowicz died in 1936. A year later, the University of Poznań employed Władysław Orlicz, a young, 34 year-old mathematician from the Lvov School. Orlicz continued the development of the Poznań department of mathematics and established his own scientific school. Professor Zdzisław Krygowski retired in 1938, but he still conducted research and closely cooperated with the University. He lived in Poznań at Marszałka Focha 54 before the outbreak of the war. When he retired, the University employed Józef Marcinkiewicz, a young ambitious mathematician from Vilnius with great scientific achievements. Unfortunately, the outbreak of the war on 1 September 1939 made it impossible for Marcinkiewicz to take the professorship in Poznań. He was later imprisoned at Starobielsk Camp and murdered in Kharkov in 1940 - thus, Poznań was deprived of an excellent successor of Professor Zdzisław Krygowski (Ref. [4]).

Had it not been for the history, the biography of Professor Zdzisław Krygowski could finish here. However, the story continued in an unpredictable fashion. Poznań struggled with German occupation for almost six years. Due to displacement in December 1939, Krygowski lost all his property and his priceless book collection with approx. 3,000 volumes. He spent the war period in Cracow in very difficult conditions, making his living by giving private lessons. He started giving lectures at Cracow Polytechnic in 1945. Władysław Orlicz, employed at the University of Poznań as Extraordinary Professor since 1937, came back from Lvov to Poznań after the war in 1945. He brought with him 

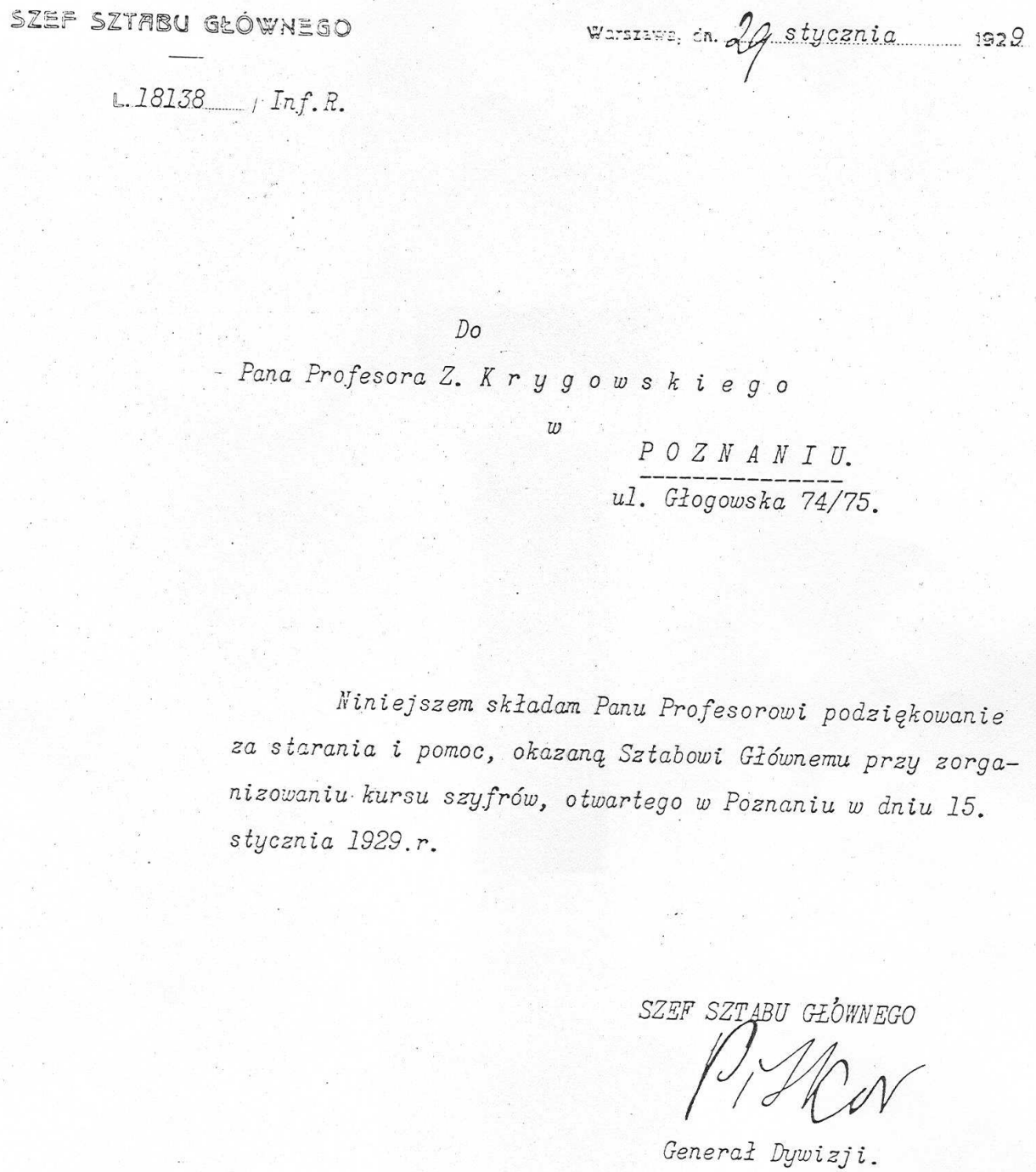

2. In this document, the Chief of General Staff of the Polish Army thanks Professor Krygowski for the organisation of the cryptology course at the University of Poznań. 
L ..18138..../Inf.R.

\section{Professor Z. Krygowski}

\section{POZNAŃ}

ul. Głogowska 74/75

I would like to extend my words of gratitude to Professor Krygowski for the commitment and assistance provided to the General Staff in the organisation of a cryptology course initiated in Poznan on 15 January 1929.

\section{CHIEF OF GENERAL STAFF}

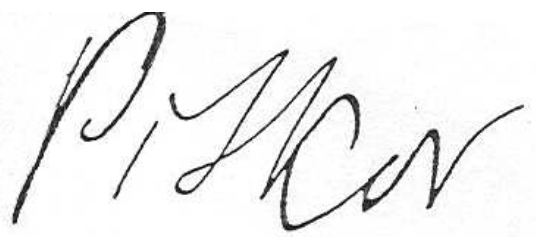

Lieutenant General 
Andrzej Alexiewicz, a young doctor from Lvov. Jerzy Albrycht, who later became Assistant Professor of the Chair of Mathematics, also came from Lvov. He was employed at the University of Poznań as Deputy Assistant in 1946. Due to insufficient staff, Professor Orlicz asked Professor Zdzisław Krygowski for help. Krygowski was 73 years old then, but he did not refuse to help and started working at the University of Poznań again, this time as Visiting Professor. He worked there until March 1955. Profesor Orlicz lectured on the mathematical analysis and the theory of real functions and functional analysis, while Assistant Professor Andrzej Alexiewicz gave lectures on differential equations.

Professor Zdzisław Krygowski agreed to give lectures on three areas of mathematics: higher algebra, differential geometry and the theory of analytic functions. In 1949, the second co-author of this article was assigned as deputy assistant, and then as junior assistant to Professor Zdzisław Krygowski to conduct classes in higher algebra, thus having an opportunity to see the Professor at work. Krygowski did not give regular lectures involving presentation of topics included in the syllabus. Students were to read about these topics individually. Krygowski focused on individual issues, describing them in much detail and focusing on motivation and on the significance of particular issues to the field of mathematics and its applications. Students were much impressed by his wide knowledge, not only related to mathematics, and digressions about the lives of scientists.

This is how Helena Smoluchowska Majchrowiczowa, a niece of a renowned physicist Marian Smoluchowski, student of the Faculty of Philosophy at the University of Poznań in 1920-1925 remembers Krygowski [7].

"When I studied, the lectures in mathematics were conducted by: Professor Zdzisław Krygowski (function theory, differential and integral calculus, differential equations, integral equations, selected topics in analysis), Professor Kazimierz Abramowicz (theory of numbers, theory of equations), Professor Władysław Ślebodziński, Professor Franciszek Włodarski (vector calculus, analytic geometry, calculus of variations, theory of geometric constructions), and Professor Bogdan Zaleski (astronomy, astrophysics).

Professor Krygowski was the most important lecturer. It is difficult for me to asses his scientific achievements, I have never been competent enough. I can just say that his lectures were wonderful, clear and very interesting to listen to. They were easy to understand thanks to clear writing on large boards in the seminar room and excellent hand-made pictures. Unfortunately, the Professor was interested mainly in classical mathematics. Unlike in the case of mathematicians working at universities in Warsaw, Lvov and Cracow, nobody in Poznań was interested in such areas as set theory, topology and probability calculus. On the other hand, the Professor lectured on many interesting selected mathematical topics that definitely went beyond the regular syllabus.

The Professor was both respected and feared by students. Some students were shaking when they were asked to write something on the blackboard and the Professor hated unclear handwriting. I remember that a mistake was made once when solving some problem at the seminar, which led to wrong 
results. The Professor and all students concentrated and started looking for the mistake. The class was over but nobody even moved. An hour passed, another hour passed and finally, much to everybody's relief, the problem was solved. But earlier nobody had even thought about leaving although some students had other classes."

He was a humanist mathematician interested in arts, music, he used to play the piano. He was a member of Société de Frédéric Chopin and kept in touch with Edouard Ganche, Chairman of Comité d'Action of this Society and publisher of Chopin's works. He wrote many articles about Chopin for Kurier Poznański in 1926-35 (see: List of works, items $34-40)$.

He married Rosalia New, an Englishwoman in 1913. Their daughter Alina (married name Korczyńska) worked as a secretary of Jan Nowak Jeziorański, director of Radio Free Europe in Munich after the Second World War.

In the post-war period Krygowski lived in Poznań as a widower on the ground floor of a university building at Libelta 14 . When his health allowed it, he spent his holidays in Zakopane. He died on 10 August 1955 and was buried in the cemetery at Lutycka Street in Poznań.

The department of mathematics grew in Poznań just like crops grow on a field. Zdzisław Krygowski was the ploughman and the field, although fallow, was well cultivated. And then came Władysław Orlicz who sowed the seeds. And the seeds were very good as they came from Lvov. To see the harvest, one has to visit the Faculty of Mathematics and Computer Science of Adam Mickiewicz University in Poznań at Morasko Campus.

\section{List of works}

\section{Scientific works on mathematics}

[1] On some class of transcendental functions and their expansions in Fourier series, Warsaw, Prace Mat.-Fiz. 5 (1894), 70-84, (in Polish).

[2] Sur les fonctions des espaces lacunaires, Bull. Soc. Math. Franc. 25 (1897), 240-243.

[3] On the theory of lacunary functions, Prace Mat.-Fiz. 9 (1898), 213-221, (in Polish).

[4] On the theory of analytic functions, Wiad. Mat. 3 (1899), 147-154, (in Polish).

[5] On some application of the theta function, Copy of a report from Gymnasium No. 1 in Przemyśl, Fundusz Naukowy, ed. J. Styfi, Przemyśl, 1900, 5-20, (in Polish).

[6] On expansion of hyperelliptic functions of the first order in Fourier series, Programme of the 2nd Real School, Lvov, 1905, (in Polish).

[7] Sur le développement des fonctions hyperelliptiques en séries trigonométriques, C. R. Acad. Sci. Paris 144 (1907), 889-892.

[8] Sur le développement des fonctions hyperelliptiques en séries trigonométriques ( $O$ rozwinięciu funkcyj hypereliptycznych na szeregi trygonometryczne), Warsaw, Prace Mat.-Fiz. 19 (1908), 21-61.

[9] Sur le développement des fonctions hyperelliptiques en séries trigonométriques, deuxième partie, Warsaw, Prace Mat.-Fiz. 20 (1909), 153-187. 
[10] Sur les intégrales hyperelliptiques canoniques de seconde espèce, C. R. Acad. Sci. Paris 146 (1908), 914-915.

[11] On some forms of hyperelliptic canonical integrals of the second kind and their relations with theta functions, Wiad. Mat. 12 (1908), 27-34, (in Polish).

[12] On expansion of the Jacobi function $Z(u)$ in a trigonometric series, Prace. Kom. Mat. Przyr. PTPN, D. 1., Poznań, 1922, 37-48, (in Polish).

[13] Solution d'un problème d'analyse combinatoire et son application à la théorie des determinants, Bull. Soc. Amis Sci. Poznań B 3 (1928), 67.

[14] On the solution of a problem in combinatorial analysis and its application in the theory of determinants, Wyd. PTPN, Poznań, 1928, p. 8, (in Polish).

[15] (et Lidia Seipelt), Sur une équation résolvante de l'équation de l'icosaèdre, Bull. Soc. Amis Sci. Poznań, B 4 (1930), 10-18.

[16] Sur certaines généralisations de l'équation à trois termes entre les fonctions sigma, Bull. Sci. Math. (France) (2) 60 (1936), 72-79.

[17] Remarques sur la formule de Kiepert dans la théorie des fonctions elliptiques, Bull. Sci. Math. (France) (2) 61 (1937), 110-114.

[18] Calcul du déterminant de Kiepert dans la théorie des fonctions elliptiques, Bull. Sci. Math. (France) (2) 61 (1937), 197-200.

[19] Sur une certaine famille de surfaces transcendantes, Bull. Soc. Amis Sci. Poznań, B 12 (1953), 107-111.

[20] Sur une classe des équations algébriques du cinquième degré résolubles algébriquement, Bull. Soc. Amis Sci. Poznań, B 13 (1956), 295-299.

II. Course books (all in Polish)

[21] Elements of Higher Mathematics, a lithographed course, lectures in the Polytechnic School, published by the organisation of students of Lvov Polytechnic, Lvov, 1894, $400 \mathrm{pp}$.

[22] Elements of Higher Mathematics, based on lectures by Dr. Z. Krygowski, ed. A. Marconi, student of engineering, Lvov, 1903/4, $388 \mathrm{pp}$.

[23] Lectures in Mathematics, Part 1. Differential calculus and the theory of series, published by the organisation of students of Lvov Polytechnic, Lvov, 1914, $600 \mathrm{pp}$.

\section{Other works}

\section{A. General works/reviews (all in Polish)}

[24] Leçons sur la théorie des fonctions entières par Emile Borel maître de conférences à l'Ecole normale supérieure, vol. I, eds. Gauthier-Villars et fils, Paris, 1898, VI+136 pp. [in:] Wiad. Mat. 3 (1899), 190-194.

[25] Leçons de géométrie élémentaire (Géométrie plane) par Jacques Hadamard, maître de conférences à la Faculté des Sciences de Paris, Professeur suppléant au Collège de France, eds. A. Colin et Cie, Paris, 1898, 308 pp. [in:] Wiad. Mat. 3 (1899), 198-199.

[26] On some application of the theta function. An article written by Z. Krygowski, Report from Gymnasium No. 1 in Przemyśl, ed. J. Styfi, Przemyśl, 1900, 18 pp. [in:] Wiad. Mat. 4 (1900), 253-255.

[27] Eléments de la théorie des fonctions elliptiques par Jules Tannery et Jules Molk, eds. Gauthier-Villars et fils, Paris, vol. I, 1893, 246 pp., vol. II, 1896, 299 pp., vol. III, 267 pp.; H. Burkhardt, Functionentheoretische Vorlesungen von Jules Tannery et Jules Molk, Zwei- 
ter Theil. Elliptische Functionen, Veit u. Comp. Leipzig, 1899, 373 pp. [in:] Wiad. Mat. 5 (1901), 107-110.

[28] Vorlesungen über verschiedene Gebiete der höheren Mathematik mit Berücksichtigung der Anwendungen von Fricke Robert Kurzgefasste, Professor an der technichen Hochschule zu Braunschweig, Analytische Functionen, Theoretischer Theil. Teubner, Leipzig, 1900, 507 pp. [in:] Wiad. Mat. 5 (1901), 110-111.

[29] On the argument partition equations for elliptic functions, written by Trynkowski Mikotaj, candidate for physical and mathematical sciences. Printed by Rubieszewski and Wrotnowski, Warsaw, 1900. 8 9+157 pp. [in:] Wiad. Mat. 5 (1901), 89-92.

[30] Leçons sur la théorie des fonctions entières par Emile Borel, maître de conférences a l'Ecole normale supérieure, vol. II, eds. Gauthier-Villars et fils, Paris, 1900, 124 pp. [in:] Wiad. Mat. 6 (1902), 134-143.

\section{B. Articles about history and general works (all in Polish)}

[31] Newtoniana: Woolsthorpe and Grantham, Wiad. Mat. 17 (1913), 331-337.

[32] Mathematics at the turn of the 19th and 20th centuries, Prace. Kom. Mat. Przyr. PTPN, Poznań, 1952.

\section{Translations of general works (all in Polish)}

[33] G. Peano, Definitions in mathematics, Wiad. Mat. 6 (1902), 174-181; original [in:] Bibliothèque du Congrès international de Philosophie III, Paris, 279-288.

\section{Articles about Chopin (all in Polish)}

[34] The fight over Chopin's origins, Kurier Poznański 603 (1926), p. 8.

[35] Discovering Chopin's predecessors, Kurier Poznański 595 (1926), p. 8.

[36] Further information about Chopin's family, Kurier Poznański 18 (1927), p. 8.

[37] Edouard Ganche and his collections of Chopin's mementoes, Kurier Poznański 70 (1927), p. 8.

[38] The Chopin Museum in Mallorca, Kurier Poznański 514 (1928), p. 8.

[39] Chopiniana in Mallorca, Kurier Poznański 428 (1928), p. 8.

[40] About Chopin's mementoes [E. Ganche's collection], Kurier Poznański 256 (1935), p. 8.

\section{References}

(all in Polish)

[1] J. Chudobiecki, Enigma, a virtual encryption machine, M.Sc. thesis written under the supervision of Professor Jerzy Kaczorowski, Faculty of Mathematics and Computer Science, Adam Mickiewicz University, Poznań, 2000.

[2] Zdzisław Krygowski's documents, Archives of the Krygowski family - Marta Kroemeke in Poznań.

[3] Zdzisław Krygowski's and Henryk Zygalski's Documents, Military Museum in Poznań.

[4] R. Duda, Review of S. Kalbarczyk, Polish scientists. Victims of Soviet crimes in the Second World War, Wydawnictwo Neriton, Warsaw, 2001; [in:] Wiadomości Matematyczne 40 (2004), 282-285.

[5] The History of Adam Mickiewicz University 1919-1969, series: The History of AMU 7 (1972), Poznań. 
[6] J. Garliński, Enigma. The Mystery of the Second World War, Wydawnictwo Uniwersytetu im. Marii Curie-Skłodowskiej, Lublin, 1999.

[7] M. Jaroszewska, M. Małowińska, and M. Kandulski, Research activities of mathematics and IT students at the University in Poznan 1919-1999, Adam Mickiewicz University, Faculty of Mathematics and Computer Science, Report No. 91, (1999), 1-24.

[8] M. Jaroszewska and J. Musielak, About Professor Zdzistaw Krygowski on the 50th anniversary of his death, Faculty Bulletin, XII, No. 10/113, (2005), Faculty of Mathematics and Computer Science, Adam Mickiewicz University, Poznań.

[9] W. Kozaczuk, The Battle of Mysteries. Intelligence services of Poland and the German Reich 1922-1939, Książka i Wiedza, Warsaw, 1977.

[10] Chronicles of the University of Poznan 1919-1939, Adam Mickiewicz University Library in Poznań.

[11] L. Maligranda, Władysław Orlicz (1903-1990) - His life and contribution to mathematics, [in:] Wtadystaw Orlicz. The Creator of the Poznań School of Mathematics, eds. J. Kạkol and Z. Palka, Wyd. Naukowe UAM, Poznań, 2002, 33-80.

[12] J. Musielak, Mathematics, [in:] Mathematics, Physics and Chemistry and the University of Poznań (1919-1969), Adam Mickiewicz University in Poznań, series: Outline of the University History, No. 9, Poznań, 1969, 5-16.

[13] Z. Pawlikowska, Zdzistaw Krygowski, [in:] Polish Bibliographical Dictionary, vol. XV/1, 2.64, Zakł. Nar. Ossolińskich, Wyd. PAN, Wrocław-Warsaw-Kraków, 1970, 461-462.

[14] D. Pȩdzińska, Zdzistaw Krygowski, [in:] Wielkopolska Bibliographical Dictionary, eds. A. Gạsiorowski, J. Topolski, PWN, Warsaw-Poznań, 1983, 385.

[15] Lvov Polytechnic 1844-1945, ed. R. Szewalski, Wydawnictwo Politechniki Wrocławskiej, Wrocław, 1993.

[16] Z. Poprawski, The History of Lvov Polytechnic 1844-1945, Wydawnictwo Zakład Narodowy im. Ossolińskich, Wrocław-Warsaw-Cracow, 1992.

[17] M. Rejewski, How Polish mathematicians broke the Enigma code, Wiadomości Matematyczne 23 (1980), 1-28.

[18] Outlines to the portraits of the representatives of the Poznan medical community 19451985, eds. J. Hasik, R. K. Meissner, Poznań University of Medical Sciences, Poznań, 1991.

[19] The University of Poznań in the first years of its existence (1919-1922/23), ed. A. Wrzosek, Poznań, 1924.

[20] The report on staff - Zdzistaw Krygowski's files, Archives of the Adam Mickiewicz University in Poznań.

[21] http://www.nifc.pl/icich/show.php 